GRASAS Y ACEITES 70 (2)

April-June 2019, e305

ISSN-L: 0017-3495

https://doi.org/10.3989/gya.0703182

\title{
A real case study on the physicochemical changes in crude palm oil (Elaeis guineensis) during the deep-frying of akara, traditional cowpea-paste balls, in Brazil
}

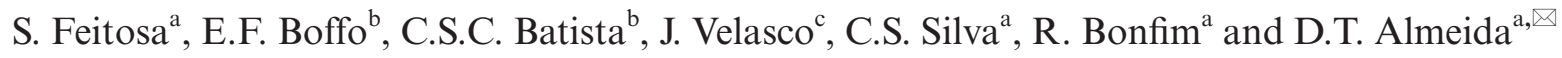 \\ ${ }^{a}$ School of Nutrition, Federal University of Bahia - UFBA, Av. Araújo Pinho 32, 40110-150, Salvador, Bahia, Brazil. \\ ${ }^{b}$ Department of Organic Chemistry, Institute of Chemistry, Federal University of Bahia - UFBA, 40170-290, Salvador, Bahia, Brazil. \\ 'Instituto de la Grasa, Consejo Superior de Investigaciones Científicas (CSIC), Campus \\ Universidad Pablo de Olavide, Ctra. de Utrera km 1, E-41013 Sevilla, Spain. \\ \Corresponding author: delia@ufba.br
}

SUMMARY: The objective of this study was to evaluate the physicochemical changes in crude palm oil during a real case of deep-frying of akara, cowpea-paste balls, fried and sold in the streets of Brazil. Discontinuous frying over five consecutive days, using 5-h frying a day, was performed according to traditional practices. The formation of polar compounds was evaluated by the IUPAC official method and by quick tests based on measures of physical properties, Testo 270 and Fri-check. In addition, ${ }^{1} \mathrm{H}-\mathrm{NMR}$ spectroscopy was applied to evaluate physicochemical changes. The results showed that after 15-h frying the total content of polar compounds (TPC) exceeded the limit of $25 \%$ established in most of the recommendations and regulations on heated oils. Such a level was reached quickly due to the high content of hydrolytic compounds present in the fresh oil and to the inappropriate use of blends of fresh and used oil in the oil replenishment. The two quick tests presented significantly lower values for TPC than the official method, probably due to the elevated hydrolysis of the fresh oil. In contrast, ${ }^{1} \mathrm{H}-\mathrm{NMR}$ results exhibited changes in the fatty acid composition which were similar to those provided by the common GC analysis. The use of crude palm oils of better initial quality and replenishment with fresh oil only are recommended to improve the quality of the oil absorbed by akara.

KEYWORDS: Akara; Crude palm oil; Deep-frying; Fri-check; NMR; Testo

RESUMEN: Estudio de un caso real sobre los cambios fisicoquímicos del aceite de palma crudo (Elaeis guineensis) durante la fritura de akara, albóndigas de pasta de alubia tradicionales, en Brasil. El objetivo de este estudio fue evaluar los cambios fisicoquímicos del aceite de palma crudo durante un caso real de fritura de akara, pasta de alubia con forma redondeada preparada y vendida en la calle en Brasil. Akara fue preparada de acuerdo con prácticas tradicionales. Se aplicó fritura discontinua en cinco días consecutivos, utilizando 5 horas de fritura al día. La formación de compuestos polares se evaluó mediante el método oficial IUPAC y mediante pruebas rápidas basadas en medidas de propiedades físicas, Testo 270 y Fri-check. Además, se aplicó espectroscopía

${ }^{1} \mathrm{H}-\mathrm{RMN}$ para evaluar cambios fisicoquímicos. Los resultados mostraron que después de 15 horas de fritura el contenido total de compuestos polares (CPT) excedía el límite del $25 \%$ establecido en la mayoría de las recomendaciones y regulaciones sobre aceites calentados. Este nivel fue alcanzado rápidamente debido al alto contenido de compuestos hidrolíticos detectados en el aceite fresco y al uso inapropiado de mezclas de aceite fresco y usado utilizadas para la reposición de aceite. Las dos pruebas rápidas presentaron valores significativamente más bajos de CPT que el método oficial, probablemente debido a la elevada hidrólisis del aceite fresco. Por el contrario, los resultados de ${ }^{1} \mathrm{H}-\mathrm{R} M N$ exhibieron cambios en la composición de ácidos grasos que fueron similares a los proporcionados por el análisis común de CG. Se recomienda el uso de aceites de palma crudos de mejor calidad inicial y reposición únicamente con aceite fresco para mejorar la calidad de akara.

PALABRAS CLAVE: Aceite de palma crudo; Akara; Fri-check; Fritura; RMN; Testo

ORCID ID: Feitosa S https://orcid.org/0000-0001-5102-6452, Boffo EF https://orcid.org/0000-0003-2514-1769, Batista CSC https://orcid.org/0000-0002-8454-3525, Velasco J https://orcid.org/0000-0003-4206-3037, Silva CS https://orcid.org/0000-0002-0736-5817, Bonfim R https://orcid.org/0000-0001-5908-9597, Almeida DT https://orcid. org/0000-0001-8839-5075

Citation/Cómo citar este artículo: Feitosa S, Boffo EF, Batista CSC, Velasco J, Silva CS, Bonfim R, Almeida DT. 2019. A real case study on the physicochemical changes in crude palm oil (Elaeis guineensis) during the deep-frying of akara, traditional cowpea-paste balls, in Brazil. Grasas Aceites 70 (2), e305. https://doi.org/10.3989/gya.0703182

Copyright: (C2019 CSIC. This is an open-access article distributed under the terms of the Creative Commons Attribution 4.0 International (CC BY 4.0) License. 


\section{INTRODUCTION}

Palm oils derive from the palm tree fruit (Elaies guineensis) with a balanced ratio of unsaturated and saturated fatty acids: $40 \%$ oleic acid (monounsaturated fatty acid); $10 \%$ linoleic acid (polyunsaturated fatty acid); $45 \%$ palmitic acid and 5\% stearic acid (saturated fatty acids). It is a rich source of phytonutrients such as tocotrienols, tocopherols, carotenoids, phytosterols, squalene, and coenzyme Q10, all of which exhibit nutritional properties and contribute to increasing the oxidative stability (Baharin, et al., 2001; Almeida et al., 2013).

Numerous studies over more than 50 years have evaluated the physicochemical properties and frying performance of refined, bleached, and deodorized palm oil (PO) (Machado et al., 2008; Koushki et al., 2015; Aniołowska and Kita, 2016). Palm oil is one of the most widely produced and consumed oils in the world. It is used in more than 150 countries (USDA, 2018). However, studies on crude palm oil (CPO), especially those regarding physicochemical changes during frying are scarce (Felzenszwalb et al., 2014; Almeida et al., 2015; 2017; Correia et al., 2017).

CPO has been used in the Bahian tradition for centuries, having been brought to Brazil from Africa by slaves in the 16th century. This CPO is part of the recreation of a sophisticated and extensive Bahian cuisine and is undoubtedly one of the major contributions to the Brazilian culinary, indispensable in numerous typical dishes of Brazil (Almeida et al., 2013).

Regarded as one of Brazil's irreplaceable national treasures, akara is a fried bean paste made in Brazil. It is prepared and sold in the streets by women dressed in regional costumes called baianas de acarajé. In its making, the cowpeas (Vigna unguiculata L. Walp) are split, decorticated and macerated into a paste. Then it is seasoned with grated onions and salt, shaped into balls with a wooden spoon and deep-fried in CPO (Rogério et al., 2014; Feitosa et al., 2015). Akara is high in protein, a source of essential micronutrients, and an inexpensive street food accessible to economically underprivileged people who often eat akara as a main meal (Feitosa et al., 2015). Its preparation is carried out with no quality control in the streets. The moment for the fat replacement relies on the experience of the person who prepares it, which is based on observable physicochemical changes, including changes in color, odor, taste or flavor and smoke release.

Deep-fat frying is a cooking method characterized by the use of high temperatures which cause degradation processes in the oil due to polymerization, oxidation and hydrolysis reactions. These lead to changes in the physical, chemical and nutritional properties of the oil. The formation of toxic compounds along with the reduction in natural antioxidants jeopardizes the nutritional essence and health benefits of the frying oil (Falade et al., 2017). In most countries with regulation or recommendations on edible oils heated at frying temperatures, the level of degradation is limited to $25 \%(\mathrm{w} / \mathrm{w}$ ) total polar compounds (TPC) (Firestone, 2007), named as such because of their greater polarity compared to the non-altered triacylglycerols. In Bahia, lowquality $\mathrm{CPO}$ is usually obtained from fruit that is deteriorated because of inadequate agricultural treatments and harvest techniques (Almeida et al., 2013). When the fruit undergoes damage, both endogenous and also exogenous lipases of microbial origin come into contact with the oil and catalyze the hydrolytic degradation (Sambanthamurthi et al., 2000).

Considering the relevance of akara in Brazil and the few frying studies regarding its $\mathrm{CPO}$, the objective of the present work was to evaluate the physicochemical changes taking place in CPO during the deep-frying of akara in order to know the quality of the oil incorporated into the food. A follow-up study during the discontinuous frying preparation of akara was performed. The formation of polar compounds was evaluated by the IUPAC official method and by the quick tests based on the measurements of physical properties, Testo 270 and Fri-check. In addition, H-NMR spectroscopy was applied to evaluate physicochemical changes. Both the quick tests and the spectroscopic method were assessed to determine their utility.

\section{MATERIALS AND METHODS}

\subsection{Oil samples}

The preparation of akara was carried out by a baiana de acarajé according to traditional practices (Rogério et al., 2014). A volume of $30 \mathrm{~L}$ of CPO (a mixture of liquid and solid phases) obtained by industrial extraction at Nazaré city (Brazil) and conditioned in tinplate cans was acquired at São Joaquim Fair, in Salvador city (Brazil). The oil was completely homogenized at $45{ }^{\circ} \mathrm{C}$. A volume of $20 \mathrm{~mL}$ of the fresh oil was filtered in a glass wool filter, protected with nitrogen gas and stored in an amber bottle at $-20{ }^{\circ} \mathrm{C}$ until analysis (Jorge and Gonçalves, 1998).

The frying was always performed outdoors. The total frying time was $5 \mathrm{~h}$ a day and the frying process was carried out over 5 consecutive days. The deepfrying began with $5 \mathrm{~L}$ of $\mathrm{CPO}$, which were heated in an enameled pan $(10 \mathrm{~L}$ capacity; 46 and $26 \mathrm{~cm}$ external and internal diameter, respectively; $13 \mathrm{~cm}$ high) for $12 \mathrm{~min}$ in the presence of a white onion $(\sim 60 \mathrm{~g})$. Five units of raw mass (uniform balls of $95 \mathrm{~g}$ each) were successively added and deep-fried in the CPO $(475 \mathrm{~g} / \mathrm{L}$ of oil). The frying temperature ranged from 143 to $188{ }^{\circ} \mathrm{C}$ in the beginning (day 1) and 
$159-178{ }^{\circ} \mathrm{C}$ in the end (day 5). At the end of each day the oil was decanted, filtered hot and stored at room temperature in an enameled pan with a cover until the next day. The same procedure was repeated over the following four days. The total frying time was $25 \mathrm{~h}$.

Replenishment with oil was performed according to the baiana's practices. Fresh oil was added on days 1 and 2, whereas blends of fresh and used oil were added during the following days (Table 1).

\subsection{Analytical determinations}

\subsubsection{Total carotenoids}

The total content of carotenoids was analyzed by spectrophotometry according to Rodriguez-Amaya and Kimura (2004). The analysis was performed in triplicate.

\subsubsection{Peroxide value ( $P V)$}

Peroxides were analyzed in triplicate following the AOCS method Cd 8b-90 (AOCS, 2003).

\subsubsection{Oxidative stability index (OSI)}

The OSI of the oil samples was performed in triplicate in a Rancimat device, using a 743 model (Metrohm CH-9101, Herisau, Switzerland). Three grams of the oil were weighed into the reaction vessel and the measurements were taken at $120^{\circ} \mathrm{C}$ with an airflow of $20 \mathrm{~L} / \mathrm{h}$ (Läubli and Bruttel, 1986).

\subsubsection{Total polar compounds (TPC)}

Standard method. The TPC content was determined by adsorption chromatography according to Dobarganes et al., (2000) with slight modifications. A solution of $0.5 \mathrm{~g} / \mathrm{mL}$ of $\mathrm{CPO}$ in the elution solvent was fractionated into a glass column $(150 \mathrm{~mm}$ long, $10 \mathrm{~mm}$ i.d.) filled with silica gel (particle size $0.063-$ $0.200 \mathrm{~mm}$ and $70-230 \mathrm{mesh}$ ). The silica was prepared using $5 \mathrm{~g}$ in $10 \mathrm{~mL}$ of the elution solvent. The water content of the silica gel was previously adjusted to $5 \%$. The elution solvent consisted of light petroleum (b.p. $40-60{ }^{\circ} \mathrm{C}$ ) and diethyl ether $94: 6(\mathrm{v} / \mathrm{v})$. A first fraction consisting of the non-polar compounds was obtained with $60 \mathrm{~mL}$ of the elution solvent. Then the fraction of polar compounds was eluted with $50 \mathrm{~mL}$ diethyl ether. The solvent was evaporated in a rotary evaporator and then with a stream of nitrogen. The total content of polar compounds was determined gravimetrically.

Testo 270. The samples were analyzed by inserting the Testo sensor into the hot oil $\left(45^{\circ} \mathrm{C}\right)$. The measurements were taken after $30 \mathrm{~s}$. The sensor was calibrated before the analyses.

Fri-check. The Fri-check measurements were made at $52{ }^{\circ} \mathrm{C}$ following the procedure described by Osawa et al., (2012).

\subsubsection{Composition of polar compounds}

The polar fractions obtained in the standard method were in turn analyzed by high-performance size-exclusion chromatography (HPSEC) with refractive index detection to determine triacylglycerol polymers (TGP), triacylglycerol dimers (TGD), oxidized triacylglycerol monomers (oxTGM), diacylglycerols (DG) and free fatty acids (FFA), i.e. groups of compounds with different molecular weight, according to Dobarganes et al., (2000). The polar fractions were dissolved in tetrahydrofuran at a concentration of $10 \mathrm{mg} / \mathrm{mL}$ and analyzed by HPSEC. The HPSEC chromatograph was equipped with a Rheodyne $7725 \mathrm{i}$ injector with a $10-\mu \mathrm{L}$ sample loop, a Knauer 120 HPLC pump (Knauer, Berlin, Germany) and a Merck L-7490 refractive index detector (Merck, Darmstadt, Germany). Two 100 and 500 À Ultrastyragel columns $(25 \mathrm{~cm} \times 0.77 \mathrm{~cm}$ i.d.) packed with porous, highly cross-linked styrene-divinylbenzene copolymers $(5 \mu \mathrm{m})$ (Agilent Technologies, Palo Alto, CA) were used. Tetrahydrofuran at $1 \mathrm{~mL} / \mathrm{min}$ was the mobile phase.

\subsubsection{Fatty acid composition}

The fatty acid composition was determined according to the method of the Institute Adolfo Lutz (IAL, 2005) to transform the fatty acyl chains

TABLE 1. Initial and final volume (L) of oil in the pan and replenishment during the discontinuous frying of akara.

\begin{tabular}{|c|c|c|c|c|c|c|}
\hline & & DAY 1 & DAY 2 & DAY 3 & DAY 4 & DAY 5 \\
\hline Initial Oil & & 5 & $4^{a}$ & $3.5^{\mathrm{b}}$ & $3.5^{\mathrm{d}}$ & $4^{\mathrm{f}}$ \\
\hline \multirow[t]{2}{*}{ Replenishment } & Fresh Oil & 2 & 3 & 1.5 & - & - \\
\hline & Used Oil & - & - & $1.3^{\mathrm{c}}$ & $\begin{array}{l}1.5^{\mathrm{c}} \\
0.7^{\mathrm{e}}\end{array}$ & $2.3^{\mathrm{e}}$ \\
\hline Final Oil & & $4^{\mathrm{a}}$ & $5.6^{\mathrm{b}}$ & $4.8^{\mathrm{d}}$ & $4^{\mathrm{f}}$ & 5.2 \\
\hline
\end{tabular}

a used oil on DAY $1 ;{ }^{\mathrm{b}}$ used oil on DAY 2 ; ${ }^{\mathrm{c}}$ blend of $3 \mathrm{~L}$ of fresh oil with $2.1 \mathrm{~L}$ of oil b; ${ }^{\mathrm{d}}$ used oil on DAY 3 ; $^{\mathrm{e}}$ blend of $1 \mathrm{~L}$ of fresh oil with $1.3 \mathrm{~L}$ of oil d; ${ }^{\mathrm{f}}$ used oil on DAY 4 . According to baiana's practice, the oil was added when the volume was reduced. 
into fatty acid methyl esters (FAME) followed by gasliquid chromatography. A Shimadzu gas chromatograph, 17A model, (Shimadzu gas, Japan) equipped with a split/splitless injector, a CP-Sil 88 capillary column $(100 \mathrm{~m} \times 0.25 \mathrm{~mm}$ i.d., $0.25 \mu \mathrm{m}$ film thickness) (CP 7420 Varian, EUA) and a flame ionization detector (FID) was used. The analyses were obtained using an injection volume of $1 \mu \mathrm{L}$, a split division of $1 / 40, \mathrm{He}$ as carrier gas at $1 \mathrm{~mL} \cdot \mathrm{min}^{-1}$, and applying the following temperature program: the oven temperature was held at $45^{\circ} \mathrm{C}$ for $2 \mathrm{~min}$, then increased up to $165^{\circ} \mathrm{C}$ at $20^{\circ} \mathrm{C} \cdot \mathrm{min}^{-1}$ and held for $15 \mathrm{~min}$ and then increased again to $220^{\circ} \mathrm{C}$ at $4{ }^{\circ} \mathrm{C} \cdot \mathrm{min}^{-1}$ and held for $35 \mathrm{~min}$. The injector and detector were set at $250^{\circ} \mathrm{C}$. The analyses were performed in triplicate.

The absolute amount of individual fatty acids was calculated considering that saturated fatty acids do not undergo substantial changes during frying compared to unsaturated fatty acids. Thus, the amounts of unsaturated fatty acids were corrected, supposing that the total sum of saturated fatty acids remained constant during frying (Dobarganes and Pérez-Camino, 1988).

\subsection{7. ${ }^{1} H$-NMR spectral acquisition}

CPO samples which were kept frozen at $-20^{\circ} \mathrm{C}$ were first thawed at room temperature in the dark and subsequently vortexed for $30 \mathrm{~s}$. The samples were prepared in triplicate by dissolving $30 \mathrm{mg}$ of $\mathrm{CPO}$ in $600 \mu \mathrm{L}$ of $\mathrm{CDCl}_{3}(99.8 \%)$ containing $1 \%$ TMS. The solvent was from Cambridge Isotope Laboratories, Inc. (USA). All NMR experiments were recorded at $300 \mathrm{~K}$ using a Varian Ivona 500 spectrometer operating at $11.7 \mathrm{~T}$, equipped with 5-mm direct detection probe and observing ${ }^{1} \mathrm{H}$ at $500 \mathrm{MHz}$.

${ }^{1} \mathrm{H}-\mathrm{NMR}$ spectra were acquired using a spectral width of $5,998 \mathrm{~Hz}$; 65,536 data points; pulse width of $10.1 \mu \mathrm{s}\left(90^{\circ}\right)$; relaxation delay of $3.0 \mathrm{~s}$; acquisition time of $10.9 \mathrm{~s}$ and 64 scans. The relaxation delay was determined by $T_{1}$ measurements with the aid of the pulse sequence inversion recovery and changing $\tau$ values from 0.1 to $10 \mathrm{~s}$. Spectra were processed using 32,768 data points and by applying an exponential line broadening of $0.3 \mathrm{~Hz}$ for sensitivity enhancement before Fourier transformation. The spectra were accurately phased and baseline adjusted. In order to evaluate the reproducibility of ${ }^{1} \mathrm{H}-\mathrm{NMR}$ measurements, three replicates of each sample were analyzed. Phase correction was performed manually for each spectrum, and the baseline correction was applied over the entire spectral range. The ${ }^{1} \mathrm{H}-\mathrm{NMR}$ chemical shifts were referred to the TMS signal (at $0.00 \mathrm{ppm}$ ) using ACD/NMR Processor software (Academic Edition, v. 12.01, Advanced Chemistry Development Inc.).

The absolute amount of individual fatty acids was also calculated considering that saturated fatty acids do not undergo substantial changes during frying compared to unsaturated fatty acids (Dobarganes and Pérez-Camino, 1988).

\subsubsection{Statistical analyses}

Statistical analyses were made with SPSS 24. All the analytical determinations were made in triplicate. Regression analysis was applied to evaluate the relationships between the chemical and physical degradation parameters. The model fitting was judged by the coefficient of determination $\left(R^{2}\right)$. Linear correlation was assessed by Sperman's correlation $(r)$. One-factor ANOVA was applied sample by sample to evaluate the differences among the standard method of polar compounds, the Testo and Fri-check tests. Differences among means were determined by Tukey's test. In order to evaluate physicochemical changes in the oil throughout the frying time the General Linear Model (GLM) with repeated measurements was applied. Differences between pair of means were determined by Bonferroni's test. Significance was established at $p<0.05$.

\section{RESULTS AND DISCUSSION}

\subsection{Characterization of the fresh oil}

The results obtained for the fresh oil are listed in Table 2. The fatty acid composition and levels of carotenoids were typical of an Elaeis guineensis palm oil, presenting a proportion of saturated and unsaturated fatty acids of almost 50:50\% and carotenoid contents of nearly $600 \mathrm{mg} / \mathrm{kg}$ oil. The contents of individual fatty acids and total carotenoids were within the ranges found in the Codex Alimentarius (2017) and those previously reported for Brazilian crude palm oils (Almeida et al., 2013). The PV also corresponded to normal values for crude oils according to Codex Alimentarius (2017), which recommends a maximum of $15 \mathrm{meq} \mathrm{O}_{2} / \mathrm{kg}$ oil. The levels of polar compounds were relatively high, but common for crude palm oil (Almeida et al., 2013). The analysis of the polar components by HPSEC showed that the polar fraction was mainly constituted by hydrolytic degradation products, diacylglycerols and free fatty acids. This fact is frequent in crude oils obtained from unhealthy or damaged oleaginous fruits (Sambanthamurthi et al., 2000). The oxidative stability index determined by Rancimat was also within the range reported for crude palm oil (Almeida et al., 2013).

\subsection{Physicochemical changes of the oil during deep-frying}

Polar compounds. The total content of polar compounds (TPC) has been widely used to evaluate the quality of frying oils. They correspond to the 
TABLE 2. Physicochemical characterization of the fresh crude palm oil (CPO).

\begin{tabular}{lcc}
\hline & CODEX & CPO \\
\hline Fatty acid composition (\%) & nd & nd \\
C10:0 & nd- 0.5 & $0.21 \pm 0.03$ \\
C12:0 & $0.5-2.0$ & $0.75 \pm 0.07$ \\
C14:0 & $39.3-47.5$ & $39.19 \pm 0.00$ \\
C16:0 & $3.5-6.0$ & $5.48 \pm 0.07$ \\
C18:0 & $36.0-44.0$ & $43.3 \pm 3.7$ \\
C18:1 & $9.0-12.0$ & $10.62 \pm 0.00$ \\
C18:2 & nd-1.0 & $0.07 \pm 0.10$ \\
C20:0 & nd- 0.5 & nd \\
C18:3 & & $45.7 \pm 0.1$ \\
Saturated & & $54.3 \pm 3.7$ \\
Unsaturated & & $584.9 \pm 5.0$ \\
Carotenoids (mg/kg) & & $4.8 \pm 0.1$ \\
PV (meq/kg) & & $15.2 \pm 0.1$ \\
TPC (\%) & & nd \\
TGP (\%) & & nd \\
TGD (\%) & & $1.3 \pm 0.1$ \\
oxTGM (\%) & & $8.7 \pm 1.2$ \\
DG (\%) & & $5.2 \pm 0.5$ \\
FFA* (\%) & & $4.8 \pm 0.0$ \\
OSI ${ }_{\mathbf{1 2 0}}$ (h) & & \\
\hline
\end{tabular}

nd, not detected; PV, peroxide value; TPC, total polar compounds; TGP, triacylglycerol polymers; TGD, triacylglycerol dimers; oxTGM, oxidized triacylglycerol monomers; DG, diacylglycerols; FFA $^{*}$, free fatty acids and minor polar components; $\mathrm{OSI}_{120}$, oxidative stability index measured at $120^{\circ} \mathrm{C}$. Results express the mean value \pm standard deviation $(n=3)$.

products formed through the major reactions that take place during frying. The TPC is comprised of polymerized triacylglycerols, oxidized triacylglycerols, diacylglycerols and free fatty acids, i.e. compounds formed by thermal, oxidative and hydrolytic degradation, respectively (Dobarganes et al., 2000).

The changes in TPC contents observed in the oil during frying are shown in Table 3.

The TPC content increased linearly with the frying time $\left(\mathrm{R}^{2}=0.96\right)$, as observed in numerous frying studies (Olivero-David et al., 2017). However, no significant increment was found from the first to the second day of frying, i.e. between the oils used during 5 and $10 \mathrm{~h}$, respectively. This fact can be attributed to the addition of fresh oil. Not only does the addition of fresh oil cause a dilution effect on the degradation products, but also it exerts some protection because of the reposition of antioxidants (Romero et al., 1998). After 15-h frying, the CPO exceeded the limit of $25 \%$ established in most of
TABLE 3. Contents of total polar compounds (TPC) determined by the standard method and estimated by Testo 270 and Fri-check in the CPO during frying.

\begin{tabular}{lcrc}
\hline Frying time (h) & TPC (\%) & Testo 270 (\%) & Fri-check (\%) \\
\hline $\mathbf{0}$ & $14.0 \pm 0.1 \mathrm{c}$ & $9.5 \pm 0.5 \mathrm{~b}$ & $5.2 \pm 0.7 \mathrm{a}$ \\
$\mathbf{5}$ & $20.2 \pm 1.5 \mathrm{c}$ & $11.5 \pm 0.0 \mathrm{~b}$ & $6.5 \pm 0.6 \mathrm{a}$ \\
$\mathbf{1 0}$ & $20.1 \pm 0.6 \mathrm{c}$ & $14.7 \pm 0.7 \mathrm{~b}$ & $7.0 \pm 0.3 \mathrm{a}$ \\
$\mathbf{1 5}$ & $24.7 \pm 0.2 \mathrm{c}$ & $17.5 \pm 0.0 \mathrm{~b}$ & $6.2 \pm 0.6 \mathrm{a}$ \\
$\mathbf{2 0}$ & $27.5 \pm 0.3 \mathrm{c}$ & $19.5 \pm 0.5 \mathrm{~b}$ & $7.9 \pm 0.4 \mathrm{a}$ \\
$\mathbf{2 5}$ & $29.8 \pm 0.7 \mathrm{c}$ & $22.2 \pm 0.3 \mathrm{~b}$ & $16.7 \pm 1.4 \mathrm{a}$ \\
\hline
\end{tabular}

Results express the mean value \pm standard deviation $(n=3)$. One-factor ANOVA was applied for comparison of means. Differences were determined applying Tukey's test. Different letters for each sample denote significant differences $(p<0.05)$.

recommendations and regulations in different countries (Firestone, 2007). This fact was concomitant with the addition of a blend of fresh and used oil from the third day of the study, which emphasizes the importance of replenishing with fresh oil.

Compared to the standard method, lower levels of TPC were provided by the two quick tests, Testo 270 and Fri-check, which ranged from 9.5 to $22.2 \%$ and from 5.2 to $16.7 \%$, respectively. These considerable differences with the standard method could be related to the unusually elevated levels of hydrolysis products found in this kind of oil. It is well known that polymerization and oxidation are the predominant reactions under frying conditions. Hydrolysis also occurs, but at a much lower level (Sebedio et al., 1996). The calibration of rapid tests, including those based on physical properties, is normally performed using common refined vegetable oils that are generally obtained from oleaginous seeds. The levels of hydrolysis products in such oils are minimal compared to those found in palm oil, and more concretely in crude oils like the one of the present study. As a result, rapid tests are calibrated to measure those changes imparted by the most abundant compounds formed during frying, i.e. polymers and oxidized triacylglycerols. As an example, the contribution of the hydrolysis products to the oil's viscosity should definitely be much lower than that produced by the polymerization compounds, which could explain the low values provided by the Fri-check test.

Despite the differences in the levels of TPC given by Testo and Fri-check, both tests showed strong linear correlations with the standard method $(r=0.860$ for Testo 270 and $r=0.947$ for Fri-check). This fact indicates that the two tests responded well to the physicochemical changes occurring in the oil during frying. In a previous study, Testo 270 also showed linear correlation with the standard method, but the correlation presented by Fri-check was poor (Almeida et al., 2017). The main difference between 
the previous study and the present work is that a great variety of frying crude palm oils (collected at each point of sale of akara) with different solid contents were evaluated at that time. Therefore, the low correlation found could have been related to the heterogeneity of the samples analyzed.

The composition of polar compounds was analyzed by HPSEC in selected samples and the results are listed in Table 4. Although no significant differences were found for the content of TPC between the oils used for 5- and 10-h frying, the proportion of the different components was slightly different. As expected, the levels of polymerization and oxidation compounds were slightly greater for the 10-h sample. In agreement with other studies, no significant differences were found for the hydrolysis compounds, i.e. DG and FFA, as a consequence of frying (Sebedio et al., 1996; Olivero-David et al., 2017). Given that the levels of hydrolysis products were high in the fresh oil, the limit of $25 \%$ TPC was reached when the thermal and oxidative degradations were not elevated compared to refined oils obtained from oleaginous seeds. This fact is of interest from the nutritional point of view because DG and FFA are the same compounds produced in the digestion of fats and therefore they do not affect the nutritional value of oils.

Fatty acid composition. As expected, the fatty acid composition determined by GC (Table 5) showed considerable losses in unsaturated fatty acids during frying. Significant losses were even detected at 5-h frying. At the end of the study the losses in oleic and linoleic acids were $13 \%$ and $26 \%$, respectively. While the relative losses were higher for the polyunsaturated fatty acid, oleic acid exhibited a greater decrease in absolute amounts $(5.6 \mathrm{~g} / 100 \mathrm{~g}$ of oil). This fact can be attributed to the much higher content of oleic acid and especially to the interactions between the thermoxidative reactions of oleic and linoleic acids (Morales et al., 2012).

Carotenoids. A steady drop in carotenoids took place simultaneously to the formation of degradation compounds. The level of carotenoids was practically exhausted at the end of the study, falling from

TABLE 4. Formation of polar compounds in the CPO during frying.

\begin{tabular}{lcccccl}
\hline Frying time (h) & Total (\%) & TGP (\%) & TGD (\%) & oxTGM (\%) & DG (\%) & FFA* (\%) \\
\hline $\mathbf{0}$ & $15.2 \pm 0.1 \mathrm{a}$ & - & - & $1.3 \pm 0.1 \mathrm{a}$ & $8.7 \pm 1.2 \mathrm{ab}$ & $5.2 \pm 0.5 \mathrm{ab}$ \\
$\mathbf{5}$ & $20.2 \pm 1.5 \mathrm{~b}$ & $1.8 \pm 0.2 \mathrm{a}$ & $0.7 \pm 0.1 \mathrm{a}$ & $3.2 \pm 0.2 \mathrm{~b}$ & $8.7 \pm 0.6 \mathrm{ab}$ & $5.7 \pm 0.4 \mathrm{~b}$ \\
$\mathbf{1 0}$ & $20.1 \pm 0.6 \mathrm{~b}$ & $2.3 \pm 0.2 \mathrm{~b}$ & $0.8 \pm 0.0 \mathrm{a}$ & $4.6 \pm 0.2 \mathrm{c}$ & $7.6 \pm 0.3 \mathrm{a}$ & $4.7 \pm 0.2 \mathrm{a}$ \\
$\mathbf{2 5}$ & $29.8 \pm 0.7 \mathrm{c}$ & $6.1 \pm 0.1 \mathrm{c}$ & $2.0 \pm 0.1 \mathrm{~b}$ & $6.4 \pm 0.2 \mathrm{~d}$ & $10.0 \pm 0.3 \mathrm{~b}$ & $5.3 \pm 0.3 \mathrm{ab}$ \\
\hline
\end{tabular}

For abbreviations, see Table 1. Results express the mean value \pm standard deviation $(n=3)$. The GLM with repeated measurements was applied for comparison of means $(n=3)$. Differences were determined applying Bonferroni's test. Different letters for a given group of compounds denote significant differences $(p<0.05)$.

TABLE 5. Changes in the fatty acid composition* of the CPO during frying.

\begin{tabular}{lcccccc}
\hline & $\mathbf{0 ~ h}$ & $\mathbf{5} \mathbf{h}$ & $\mathbf{1 0} \mathbf{h}$ & $\mathbf{1 5} \mathbf{h}$ & $\mathbf{2 0} \mathbf{h}$ & $\mathbf{2 5} \mathbf{h}$ \\
\hline Fatty acids & & & & & & \\
$\mathrm{C} 12: 0$ & $0.21 \pm 0.03$ & $0.21 \pm 0.00$ & $0.21 \pm 0.01$ & $0.21 \pm 0.00$ & $0.20 \pm 0.00$ & $0.20 \pm 0.00$ \\
$\mathrm{C} 14: 0$ & $0.75 \pm 0.07$ & $0.73 \pm 0.00$ & $0.73 \pm 0.04$ & $0.73 \pm 0.00$ & $0.72 \pm 0.01$ & $0.73 \pm 0.00$ \\
$\mathrm{C} 16: 0$ & $39.19 \pm 0.00$ & $39.35 \pm 0.25$ & $39.35 \pm 2.20$ & $39.38 \pm 0.04$ & $39.38 \pm 0.43$ & $39.37 \pm 0.02$ \\
$\mathrm{C} 18: 0$ & $5.48 \pm 0.07$ & $5.28 \pm 0.02$ & $5.30 \pm 0.29$ & $5.31 \pm 0.00$ & $5.33 \pm 0.05$ & $5.35 \pm 0.01$ \\
$\mathrm{C} 18: 1$ & $43.27 \pm 3.70 \mathrm{a}$ & $39.09 \pm 0.19 \mathrm{ab}$ & $39.09 \pm 2.36 \mathrm{ab}$ & $38.40 \pm 0.02 \mathrm{ab}$ & $38.11 \pm 0.39 \mathrm{~b}$ & $37.68 \pm 0.06 \mathrm{~b}$ \\
$\mathrm{C} 18: 2 \mathrm{t}$ & - & $0.51 \pm 0.00$ & $0.51 \pm 0.03$ & $0.51 \pm 0.00$ & $0.50 \pm 0.00$ & $0.49 \pm 0.00$ \\
$\mathrm{C} 18: 2$ & $10.62 \pm 0.00 \mathrm{a}$ & $9.57 \pm 0.04 \mathrm{~b}$ & $9.22 \pm 0.52 \mathrm{bc}$ & $8.79 \pm 0.00 \mathrm{~cd}$ & $8.36 \pm 0.08 \mathrm{de}$ & $7.88 \pm 0.01 \mathrm{e}$ \\
$\mathrm{C} 20: 0$ & $0.07 \pm 0.10$ & $0.13 \pm 0.00$ & $0.13 \pm 0.01$ & $0.08 \pm 0.07$ & $0.06 \pm 0.06$ & $0.06 \pm 0.05$ \\
Saturated & $45.70 \pm 0.14$ & $45.70 \pm 0.52$ & $45.70 \pm 1.60$ & $45.70 \pm 0.32$ & $45.70 \pm 0.73$ & $45.70 \pm 0.27$ \\
Unsaturated & $53.89 \pm 3.70 \mathrm{a}$ & $49.17 \pm 0.19 \mathrm{ab}$ & $48.82 \pm 2.42 \mathrm{~b}$ & $47.70 \pm 0.02 \mathrm{~b}$ & $46.97 \pm 0.40 \mathrm{~b}$ & $46.05 \pm 0.06 \mathrm{~b}$ \\
\hline
\end{tabular}

*Corrected data considering that the saturated fatty acids remained unchanged during frying. Results express the mean value \pm standard deviation $(n=3)$. The GLM with repeated measurements was applied for comparison of means $(n=3)$. Differences were determined applying Bonferroni's test. Different letters for each fatty acid denote significant differences $(p<0.05)$. 
$584.9( \pm 5.0) \mathrm{mg} \cdot \mathrm{kg}^{-1}$ to $21.5( \pm 1.2) \mathrm{mg} \cdot \mathrm{kg}^{-1}$, which is in agreement with a previous report (Correia et al., 2017). Therefore, due to the losses in these components with antioxidant properties, the oil became partially unprotected after 25 -h frying.

Oxidative stability index. The oxidative stability index (OSI) determined by the Rancimat test is a widely used measurement of the resistance to oxidation of oils under accelerated conditions, i.e. high temperature and high oxygen availability. The OSI does not exactly provide information about the frying performance of oils because of the different conditions and reaction mechanisms involved in the test. However, it is a useful measure to evaluate

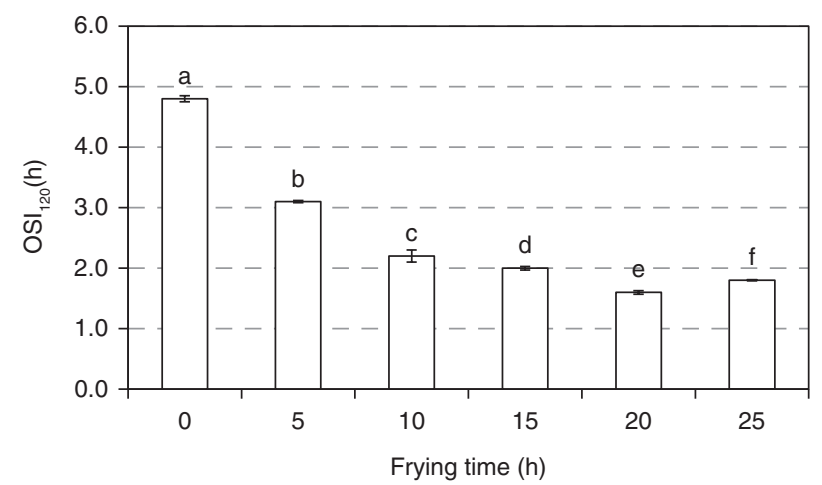

FIGURE 1. Changes in the oxidative stability index (OSI) of the crude palm oil during frying. Results express the mean value and error bars indicate the standard deviation $(n=3)$. The GLM with repeated measurements was applied for comparison of means. Differences were determined applying Bonferroni's test. Different letters denote significant differences $(\mathrm{p}<0.05)$. different oils in a short period of time and to establish a relative order of oxidative stability. Unless oxygen is not a limiting factor, the stability order given by the test should be practically the same as the one obtained at room or moderate temperature. Therefore, the OSI can be used to get to know the oxidative behavior of oils or fat-containing foods during storage (Velasco and Dobarganes, 2002). In addition, the OSI is an indirect measurement of the antioxidant/pro-oxidant balance. In fact, it can be defined as the time required for the complete depletion of antioxidants at the test conditions, i.e. when the oil becomes unprotected and oxidation is accelerated. As expected, the OSI of the oil in the present study decreased progressively during frying as a consequence of the accumulation of thermo oxidative compounds, which accelerated the oil degradation process, and the gradual loss in antioxidants outlined above (Figure 1). The OSI decreased by $62.5 \%$ at the end of the frying study.

${ }^{1} \mathrm{H}$-NMR spectroscopic measurements. ${ }^{1} \mathrm{H}-\mathrm{NMR}$ spectroscopy can be applied to quantify the fatty acid chains of triacylglycerols and so estimate the fatty acid composition (Barison et al., 2010). Figure 2 illustrates the spectra obtained in the present study. Signals A and B correspond to hydrogens bond to $\beta$ carbonyl carbons and to hydrogens bond to methylene carbons located between two double bonds (linoleate), respectively. Therefore, signals A and B are used to determine saturated and polyunsaturated fatty acids, respectively. In addition to the fatty acid composition, the ${ }^{1} \mathrm{H}-\mathrm{NMR}$ spectra also provide information on degradation products. For instance, 1,2-diacylglycerols can be estimated by hydrogens at

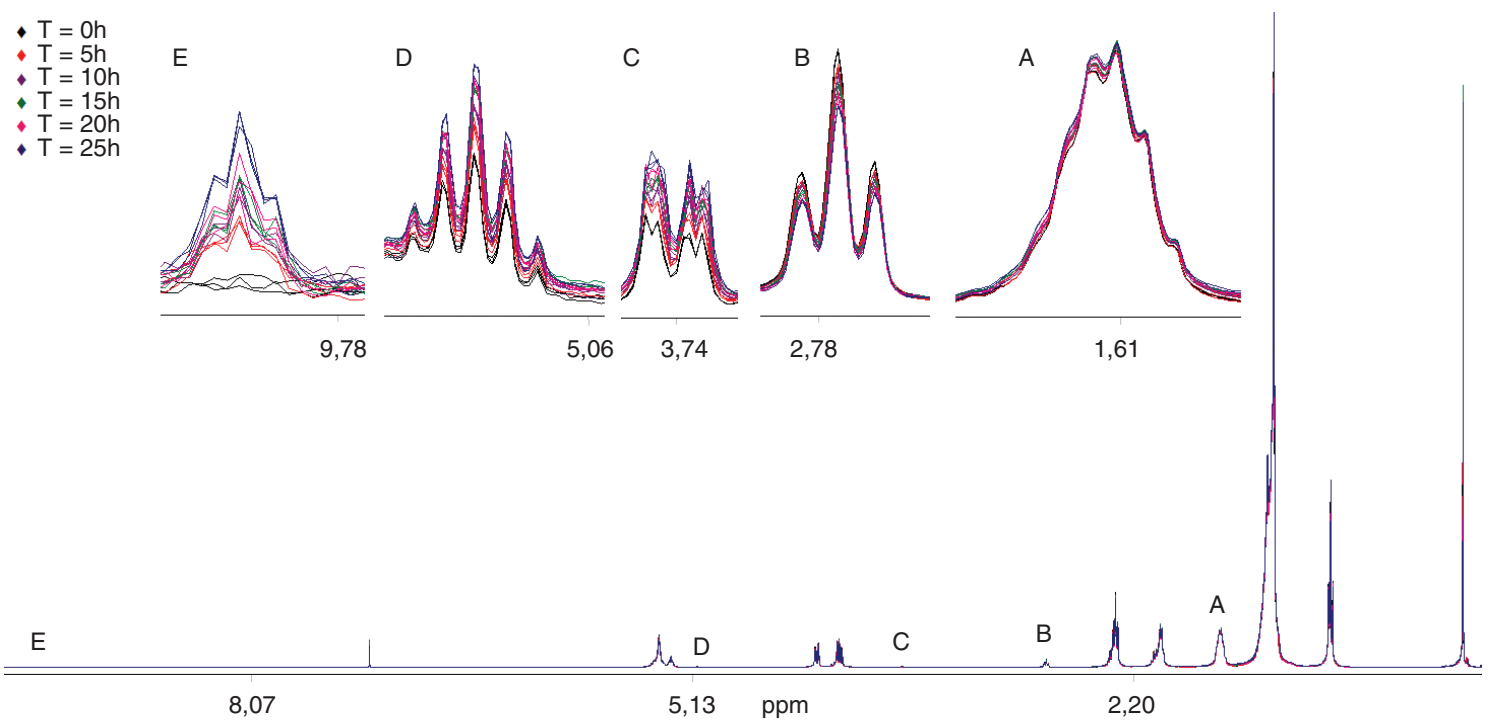

FigurE 2. ${ }^{1}$ H-NMR spectrum of the used frying oil. A: hydrogens bond to $\beta$ carbonylcarbon. B: hydrogens bond to methylene carbons located between two double bonds (linoleate). $\mathbf{C}: \mathrm{CH}_{2} \mathrm{OH}$ (sn-3) of 1,2-diacylglycerols.

D: CHOCOR (sn-2) of 1,2-diacylglycerols. E: n-aldehyde formed during heating 
TABLE 6. Changes in the fatty acid composition* measured by ${ }^{1} \mathrm{H}-\mathrm{NMR}$ in the CPO during frying.

\begin{tabular}{lcccccc}
\hline & $\mathbf{0 h}$ & $\mathbf{5 h}$ & $\mathbf{1 0 ~ h}$ & $\mathbf{1 5 h}$ & $\mathbf{2 0 ~ h}$ & $\mathbf{2 5} \mathbf{h}$ \\
\hline $\mathrm{C} 18: 1$ & $40.51 \pm 0.32 \mathrm{a}$ & $39.60 \pm 0.43 \mathrm{~b}$ & $39.00 \pm 0.32 \mathrm{c}$ & $38.72 \pm 0.18 \mathrm{de}$ & $38.30 \pm 0.45 \mathrm{de}$ & $38.13 \pm 0.37 \mathrm{f}$ \\
$\mathrm{C} 18: 2$ & $9.18 \pm 0.50 \mathrm{a}$ & $8.48 \pm 0.38 \mathrm{bc}$ & $8.24 \pm 0.81 \mathrm{bc}$ & $7.50 \pm 0.63 \mathrm{de}$ & $7.39 \pm 0.57 \mathrm{de}$ & $6.80 \pm 0.63 \mathrm{f}$ \\
$\mathrm{C} 18: 3$ & nd & nd & nd & nd & nd & nd \\
Saturated & $50.31 \pm 0.33$ & $50.31 \pm 0.61$ & $50.31 \pm 0.24$ & $50.31 \pm 0.49$ & $50.31 \pm 0.30$ & $50.31 \pm 0.43$ \\
Unsaturated & $49.69 \pm 0.72 \mathrm{a}$ & $48.09 \pm 0.62 \mathrm{~b}$ & $47.24 \pm 0.91 \mathrm{c}$ & $46.22 \pm 0.71 \mathrm{~d}$ & $45.69 \pm 0.91 \mathrm{e}$ & $44.93 \pm 0.53 \mathrm{f}$ \\
\hline
\end{tabular}

*Corrected data considering that the saturated fatty acids remained unchanged during frying. Results express the mean value \pm standard deviation $(n=3)$. nd, not detected. The GLM with repeated measurements was applied for comparison of means ( $n=3)$. Differences were determined applying Bonferroni's test. Different letters for each fatty acid denote significant differences $(p<0.05)$.

the $s n-3$ and $s n-2$ positions, which give signals $\mathrm{C}$ and D, respectively. Also, core aldehydes can be determined through signal E, which corresponds to the hydrogen of formyl groups.

The results for the fatty acid composition of the oil samples estimated by ${ }^{1} \mathrm{H}-\mathrm{NMR}$ are listed in Table 6. A significant increase in signal A was observed at the end of the frying process, indicating an increase in saturated compounds. Although this signal is normally used to show an increase in saturated fatty acids (Barison et al., 2010), the formation of methylene hydrogen does not necessarily mean the formation of single saturated fatty acids. It is known that the loss in double bounds occurs concomitantly with the formation of functional groups containing oxygen or in condensation reactions to form polymerization compounds. In this regard, the results by Frankel et al., (1981) have shown that thermally decomposed methyl oleate and methyl linoleate produced about $77 \%$ and $67 \%$ saturated compounds, respectively.

As expected, a progressive decline in linoleic acid was observed by ${ }^{1} \mathrm{H}$-NMR (Table 6), which is in agreement with the results obtained by GC. In this regard, a decrease in signal $\mathrm{C}$ with frying can be observed in Figure 2. Oleic acid also decreased in a similar way to that observed by GC.

\section{CONCLUSIONS}

The results of this study have shown that the limit of polar compounds established in most regulations and recommendations on heated fats and oils was reached when the polymerization and oxidation compounds were still low due to the high levels of hydrolysis products detected in the fresh oil. The two quick tests, Testo and Fri-check, differed from the official method for the detection of polar compounds, probably also due to the high level of hydrolysis of the fresh oil. In addition, ${ }^{1} \mathrm{H}-\mathrm{NMR}$ spectroscopy can be a useful tool for a rapid estimation of the changes in the fatty acid composition during frying. In order to improve the quality of akara, crude palm oils of better quality should be used and the traditional frying preparation should be changed to using fresh oil only for oil replenishment.

\section{ACKNOWLEDGEMENTS}

The authors are grateful for the scholarship received from Coordenação de Aperfeiçoamento de Nível Superior (CAPES) and Associação das Baianas de Acarajé e Mingau (ABAM) SalvadorBahia for their cooperation.

\section{REFERENCES}

Almeida DT, Curvelo FM, Costa MM, Viana TV, Lima PC. 2017. Oxidative stability of crude palm oil after deep frying akara (Fried Bean Paste). Food Sci. Tech-Brazil 38, 142-147. https://doi.org/10.1590/1678-457x.02217

Almeida DT, Nunes IL, Conde PL, Rosa RPS, Rogério WF, Machado ER. 2013. A quality assessment of crude palm oil marketed in Bahia, Brazil. Grasas Aceites 64, 387-394. https://doi.org/10.3989/gya.118412

AOCS. 2003. Official methods and recommended practices of the American Oil Chemists' Society. 4th ed. Champaign, USA, AOCS [AOCS Official Methods Ca 5a-40, AOCS, Cd 8b-90].

Aniołowska M, Kita A. 2016. The effect of frying on glyceryl esters content in palm oil. Food Chem. 203, 95-103. https:// doi.org/10.1016/j.foodchem.2016.02.028

Baharin BS, Latip RA, Man YC, Rahman RA. 2001. The effect of carotene extraction system on crude palm oil quality, carotene composition, and carotene stability during storage. J. Am. Oil Chem. Soc. 78, 851-855. https://doi. org/10.1007/s11746-001-0354-4

Barison A, Silva CWP, Campos FR, Simonelli F, Lenz CA, Ferreira AG. 2010. A simple methodology for the determination of fatty acid composition in edible oils through ${ }^{1}$ H-NMR spectroscopy. Mag. Reson. Chem. 48, 642-650. https://doi.org/10.1002/mrc.2629

Codex Alimentarius. 2017. Codex standard for named vegetable oils (Codex STAN 210-1999). Revision 2017

Correia LCA, Feitosa S, Matos DB, Almeida DT. 2017. Efeito da fritura de acarajé na composicão de carotenoides e atividade antioxidante de óleo de palma bruto. B. Cent. Pesqui. Proc. A 34, 1-10. https://doi.org/10.5380/cep.v34i2.53184

Dobarganes MC, Pérez-Camino MC. 1988. Fatty acid composition: a useful tool for the determination of alteration level in heated fats. Rev. Franc. Corps Gras 35, 67-70.

Dobarganes MC, Velasco J, Dieffenbacher A. 2000. Determination of polar compounds polymerized and oxidized triacylglycerols, and diacylglycerols in oils and fats. Pure Appl. Chem. 72, 1563-1575. https://doi.org/10.1351/pac20007 2081563 
Falade AO, Oboh G, Okoh AI. 2017. Potential health implications of the consumption of thermally-oxidized cooking oils - a Review. Pol. J. Food Nutr. Sci. 67, 95-105. https:// doi.org/10.1515/pjfns-2016-0028

Feitosa S,Korn MGA, Pinelli MS, Oliveira TRS, Boffo E, Greiner R, Almeida DT. 2015. Content of minerals and antinutritional factors in akara (Fried Cowpea Food). IJFPT 2, 43. https://doi.org/10.13140/RG.2.1.1456.1127

Felzenszwalb I, Mazzei JLC, Feitosa S, Aiub CF, Almeida DT. 2014. Toxicological assessment of crude palm oil (Elaeis guineensis Jacq.) used in deep frying of akara (cowpea paste finger food). Grasas Aceites 65, 1-8. https://doi.org/10.3989/ gya. 086913

Firestone D. 2007. Regulation of frying fat and oil, in Erickson MD (Ed.) Deep Frying: Chemistry, Nutrition and Practical Applications. 2nd ed, American Oil Chemists' Society Press, Champaign, USA. 373-385.

Frankel EN, Neff WE, Selke E. 1981. Analysis of autoxidized fats by gas chromatography-mass spectrometry: VII. Volatile thermal decomposition products of pure hydroperoxides from autoxidized and photosensitized oxidized methyl oleate, linoleate and linolenate. Lipids 16, 279-285. https://doi. org/10.1007/BF02534950

IAL. Instituto Adolfo Lutz. 2005. Óleos e gorduras, en IAL. ( $4^{\mathrm{a}}$ ed.) Métodos físico-químicos para análise de alimentos. Instituto Adolfo Lutz, São Paulo, 4-989.

Jorge N, Gonçalves AG. 1998. Comportamento do óleo de girassol, com alto teor de ácido oléico em termoxidação e fritura. Food Sci. Tech-Brazil 18, 335-342. https://doi. org/10.1590/S0101-20611998000300015

Koushki M, Nahidi M, Cheraghali F. 2015. Physico-chemical properties, fatty acid profile and nutrition in palm oil. JPS 6, 117-134. https://doi.org/10.22037/jps.v6i3.9772

Läubli MW, Bruttel PA. 1986. Determination of the oxidative stability of fats and oils: Comparison between the active oxygen method (AOCS Cd 12-57) and the Rancimat method. J. Am. Oil Chem. Soc. 63, 792-795. https://doi. org/10.1007/BF02541966

Loganathan R, Subramaniam KM, Radhakrishnan AK, Choo Y, Teng K. 2017. Health-promoting effects of red palm oil: evidence from animal and human studies. Nutr. Rev. 75, 98-113. https://doi.org/10.1093/nutrit/nuw054

Machado ER, Dobarganes MC, Abrantes SMP. 2008. Palm and soybean oils alterations in the discontinued frying of potatoes. Food Sci. Tech-Brazil 28, 786-792. https://doi.org/ 10.1590/S0101-20612008000400004
Morales A, Marmesat S, Dobarganes MC, Márquez-Ruiz G, Velasco J. 2012. Formation of hydroperoxy-, keto- and hydroxy-dienes in FAME from oils: Influence of temperature and addition of $\alpha$-tocopherol. J. Am. Oil Chem. Soc. 89, 675-684. https://doi.org/10.1007/s11746-011-1961-2

Olivero-David R, Mena C, Sánchez-Muniz FJ, Pérez-Jiménez MA, Holgado F, Bastida S, Velasco J. 2017. Frying performance of two virgin oils from Cornicabra olives with different ripeness indices. Grasas Aceites 68, e223. https:// doi.org/10.3989/gya.0666171

Osawa CC, Gonçalves LAG, Gumerato HF, Mendes FM. 2012. Study of the effectiveness of quick tests based on physical properties for the evaluation of used frying oil. Food Control 26, 525-530. https://doi.org/10.1016/j. foodcont.2012.01.008

Rodriguez-Amaya DB, Kimura M. 2004. Harvestplus handbook for carotenoid analysis (HarvestPlus Technical Monograph Series 2). International Food Policy Research Institute, Washington.

Rogério WF, Greiner R, Nunes IL, Feitosa S, Furtunato DMN, Almeida DT. 2014. Effect of preparation practices and the cowpea cultivar Vigna unguiculata L. Walp on the quality and content of myo-inositol phosphate in akara (fried bean paste). Food Sci. Tech-Brazil 34, 243-248. https://doi. org/10.1590/fst.2014.0040

Romero A, Cuesta C, Sánchez-Muniz J. 1998. Effect of oil replenishment during deep-fat frying of frozen foods in sunflower oil and high-oleic acid sunflower oil. J. Am. Oil Chem. Soc. 75, 161-167. https://doi.org/10.1007/s11746-998-0028-5

Sambanthamurthi R, Sundram K, Tan Y-A. 2000. Chemistry and biochemistry of palm oil. Progr. Lipid Res. 39, 507-558. https://doi.org/10.1016/S0163-7827(00)00015-1

Sebedio JL, Dobarganes MC, Márquez G, Wester I, Christie WW, Dobson G, Zwobada F, Chardigny JM, Mairot Th, Lahtinen R. 1996. Industrial production of crisps and prefried French fries using sunflower oils. Grasas Aceites 47, 5-13. https://doi.org/10.3989/gya.1996.v47.i1-2.836

USDA. 2018. Oilseeds: World Markets and Trade. United States Department of Agriculture, Foreign Agricultural Service, Office of Global Analysis. World Agricultural Outlook Board, USDA. [Online]. Available: https://apps.fas.usda. gov/psdonline/circulars/oilseeds.pdf

Velasco J, Dobarganes C. 2002. Oxidative stability of virgin olive oil. Eur. J. Lipid Sci. Technol. 104, 661-676. https:// doi.org/10.1002/1438-9312(200210)104:9/10<661::AIDEJLT661>3.0.CO;2-D 